\title{
MORTALITY CAUSED BY ARMILLARIA ROOT ROT, PERIDERMIUM RUSTS AND OTHER DESTRUCTIVE AGENTS IN LODGEPOLE PINE REGENERATION ${ }^{1}$
}

\author{
By J. A. BARANYAY and G. R. STEVENSON ${ }^{2}$
}

\begin{abstract}
Joseph Alexander Baranyay was born on September 18, 1922 in Hungary. He received the diploma in Forest Engineering in 1944 at the Forestry Faculty of the Jozsef Nador Technical University at Sopron (Hungary). He was a practising forester in Hungary until 1951 when he joined the Forestry Faculty at Sopron. He accompanied this institution when it moved to Canada in 1957. He was Assistant Professor of Forest Pathology with the University of British Columbia Faculty of Forestry, Sopron Division, until May, 1960 when he was appointed to the Forest Entomology and Pathology Laboratory, Calgary, Alta. Since that time he has been engaged in forest disease surveys and research in the Alberta region. Mr. Baranyay received the M.A. degree in 1962 from the University of British Columbia.

Grant Reed Stevenson was born in Raymond, Alberta in June 1921 and received his education at the Magrath High School. He served in the R.C.A.F. from 1941 to 1944. Upon retirement he engaged in farming under the Soldiers Settlement Act. Mr. Stevenson joined the staff of the Forest Entomology and Pathology Laboratory, Calgary, Alta., in May 1957 and has had continuous service as a research technician since that time.
\end{abstract}

\section{$A B S T R A C T$}

Surveys of diseases and other forms of damage in naturally regenerated lodgepole pine were carried out in 1959 and 1962 near Robb, Alberta in an area that had been burned in May, 1941. Eighteen and one-half per cent of the trees on seven 0.05-acre plots were dead in 1959. The additional mortality on the same plots from 1959 to 1962 was 27.7 per cent. The seemingly high mortality was not considered excessive, in light of the large numbers of trees remaining on the plots, but further examinations will show if the present high mortality rate is sustained. The most important destructive agent up to 1962 was ARMILlaria MELleA (Vahl ex Fr.) Quél. The most important non-infectious destructive agents were game and rodents.

${ }^{1}$ Contribution No. 1032, Forest Entomology and Pathology Branch, Department of Forestry, Ottawa, Canada. Costs of publication are shared with the C.I.F.

2 Forest Entomology and Pathology Laboratory, Calgary, Alberta. 
INTRODUCTION

Uncontrolled fire has played an historic and major role in the origin of lodgepole pine, Pinus contora Dougl. var latifolia Engelm., forests in Alberta. Recent advances in fire detection and suppression measures have greatly reduced the annual loss from fire in this Province, but it is likely that sizeable areas will be burned in some years. An example of this is an area of about 1,000 acres between Edson and Robb, Alberta that was burned in May 1941, since known as the Robb Burn.

The area was regenerated by natural means, mostly to pine, within about seven years of the fire. The conditions of the new stand as regards diseases and other damaging agents was investigated in 1953 (Bourchier, 1954), and again in 1957 and 1958. The disease conditions that were apparent in 1957 and 1958 prompted the initiation in 1959 (Thomas et al, 1959) of a more thorough examination based on permanent plots, since by that time considerable mortality had occurred. Periodic re-examinations of the plots were scheduled to begin in 1962. This report lists and describes the more important diseases noted in 1959 and discusses the changes that have occurred up to 1962.

The Robb Burn is located in the Upper Foothills Section of the Boreal Forest Region of Alberta (Rowe, 1959) at about 3,400 feet above sea level. The topography comprises low rounded hills. Lodgepole pine and spruce, Picea glauca (Moench) Voss and P. mariana (Mill.) B.S.P., were the main species before the fire, with some admixture of aspen, Populus tremuloides Michx. The ages of the stands varied from 30 to 60 years. The regeneration pattern following the fire and the length of the regeneration period, reflects a range of seedbed conditions and distances from seed sources. Regeneration has generally been adequate, if one agrees to accept small pockets of understocking and overstocking.

\section{METHODS}

Seven 0.05-acre plots were established in the burned area in 1959 to sample disease conditions for the apparent range of sites in the area. They were later evaluated for site quality, according to a classification used by North Western Pulp and Power Limited on whose pulp lease area the plots were located (Fig. 1). This system requires joint consideration of soil moisture, texture, and parent material and includes an estimate of productivity. Soil moisture is graded from $O$ (excessively drained) to 9 (permanently saturated sedge bog). Productivity can range from I (superior) to V (very poor).

Each of the plots was classified in this way as: Plot $\mathbf{1}$ moist sandy loam on dumped till, productivity II; Plot 2 sandy loam on dumped till that is seasonally wet to moist, productivity II; Plot 3 and 4 dumped till that is seasonally wet to moist, productivity II; Plot 5 loam seasonally wet to moist, productivity III; Plot 6 seasonally moist to dry sandy loam with large stones, productivity III; Plot 7 moist alluvial silt and sand, productivity II

The efficacy of the site classification in differentiating one plot from another was tested against the occurrence of plants of known moisture requirements. The tests showed the classification to be sufficiently sensitive to soil moisture differences for purposes of the study. 
All trees that were 12 inches and taller were tallied and the height and condition of each was noted. The ages of 10 trees adjacent to each plot were measured and the average of these was ascribed to the plot. Dead trees were uprooted, examined to learn the cause of death, and discarded. The tree tally for 1962 was therefore influenced by ingrowth from 1959. The 1962 tally of dead trees reflected only the mortality that had occurred since 1959.

\section{Results and Discussion}

Descriptive data for the 7 plots are given in Table I, together with a breakdown of the cause of tree mortality. The relative incidence of damaging agents on living trees, exclusive of root rot is presented in Table II. The incidence of root rot in living trees could not be determined accurately because of the sampling system employed. Root rot was therefore evaluated only as a mortality factor.

\section{Mortality}

Mortality that was clearly the result of infectious agents, i.e. stem rusts and root rot, amounted to 14.1 per cent by 1959 and 15.5 per cent by 1962 . An additional 2.4 per cent of the trees had been killed up to 1959 by a combination of infectious and non-infectious agents (browsing, rodents, root weevil and natural thinning). Mortality of this kind had increased to 6.3 per cent by 1962. Mortality that was clearly the result of non-infectious agents increased from 2.0 per cent in 1959 to 5.9 per cent in 1962. Total mortality at Robb had increased by 9.2 per cent from 1959 to 1962, the most rapid increases being caused by non-infectious agents (3.9 per cent) and combinations of infectious and non-infectious agents (3.9 per cent). Infectious agents by themselves caused an increase in mortality from 1959 to 1962 of only 1.4 per cent.

Ingrowth had occurred in all plots between 1959 and 1962, but only in plots 5, 6 and 7 had ingrowth resulted in a net increase in the numbers of living trees (Table I). Mortality for the period was sufficiently great in the total sample to reduce the number of living trees by 9.2 per cent despite substantial ingrowth, i.e. trees that reached a minimum size of 12 inches in height during the period.

\section{Incidence of Damage}

\section{Root rot}

Root rot caused by Armillaria mellea (Vahl ex Fr.) Quél. has been the most destructive agent at Robb. This disease has long been regarded as mainly important in non-vigorous trees (Day, 1929; Boyce, 1961). The fungus is invariably present in stands that at one time have been at least partly composed of broad-leaved trees, the stumps and roots of which provide a seemingly necessary substrate for the fungus. In the early stages of coniferous regeneration usually only scattered trees are killed, but mortality can increase up to about the time of first thinnings. As stands grow older, mortality, usually decreases coincident with the gradual disintegration of hardwood stumps and roots and a decline in the vigour of the fungus (Greig, 1962). At certain stages in their development pines are particularly susceptible 


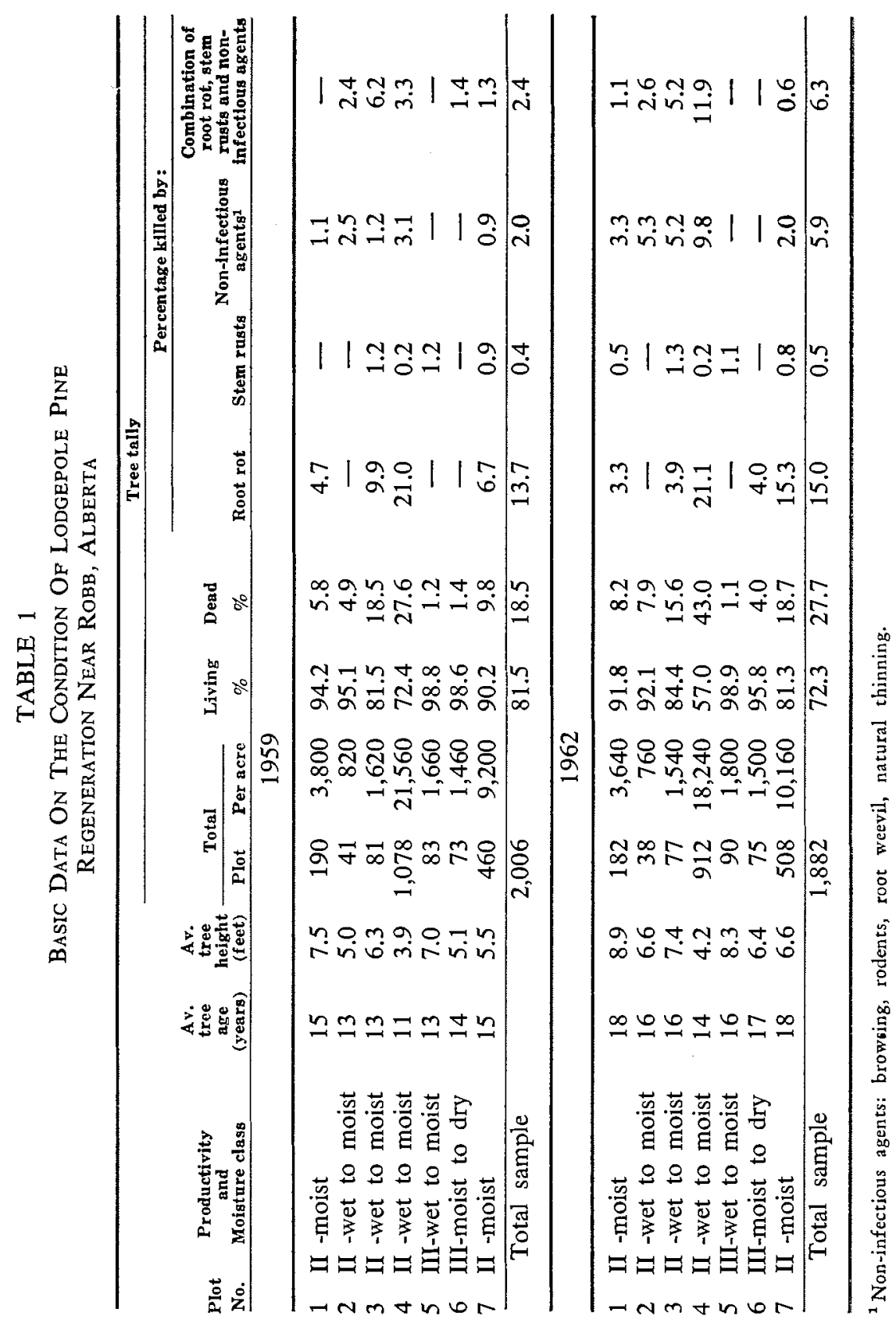




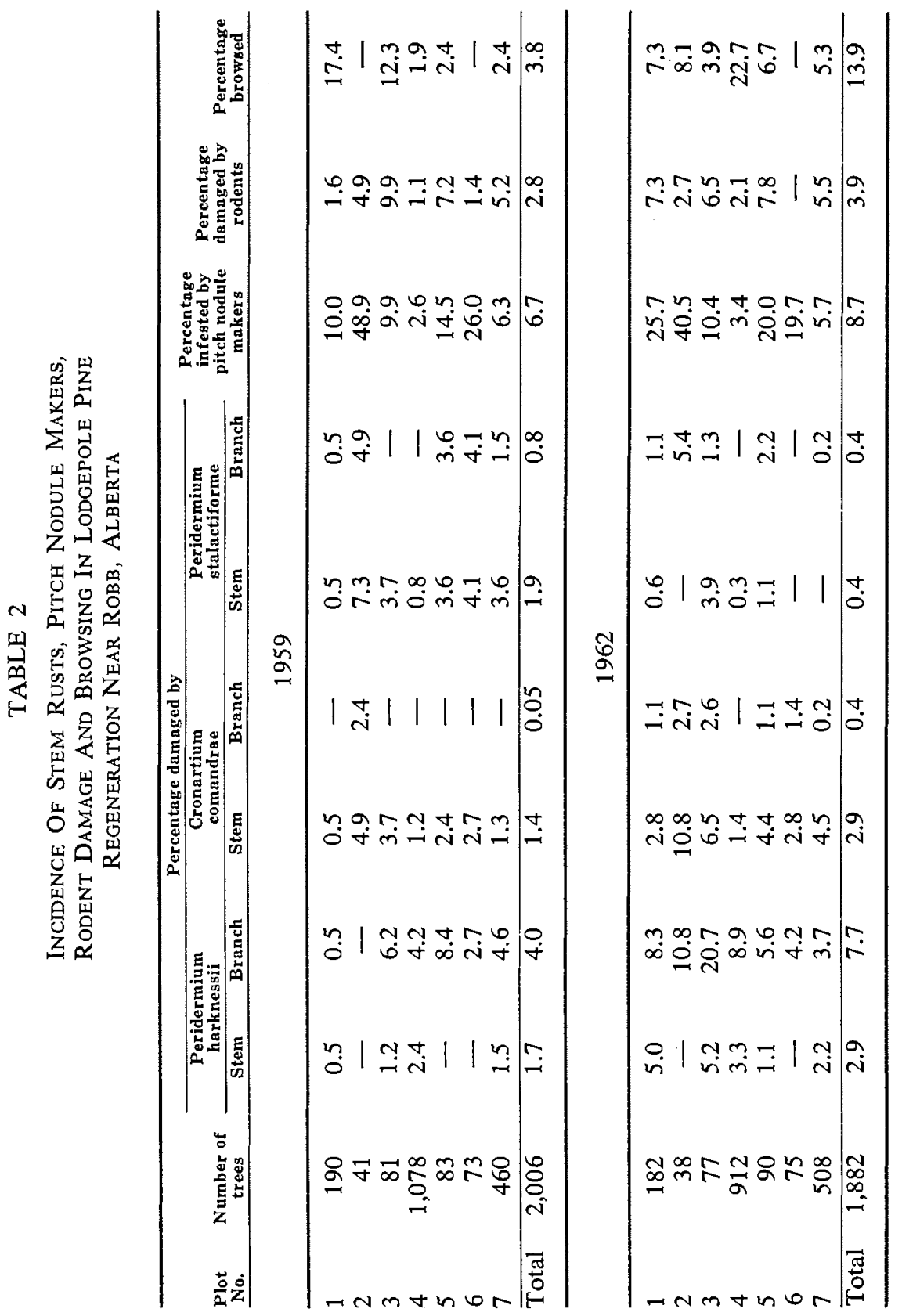




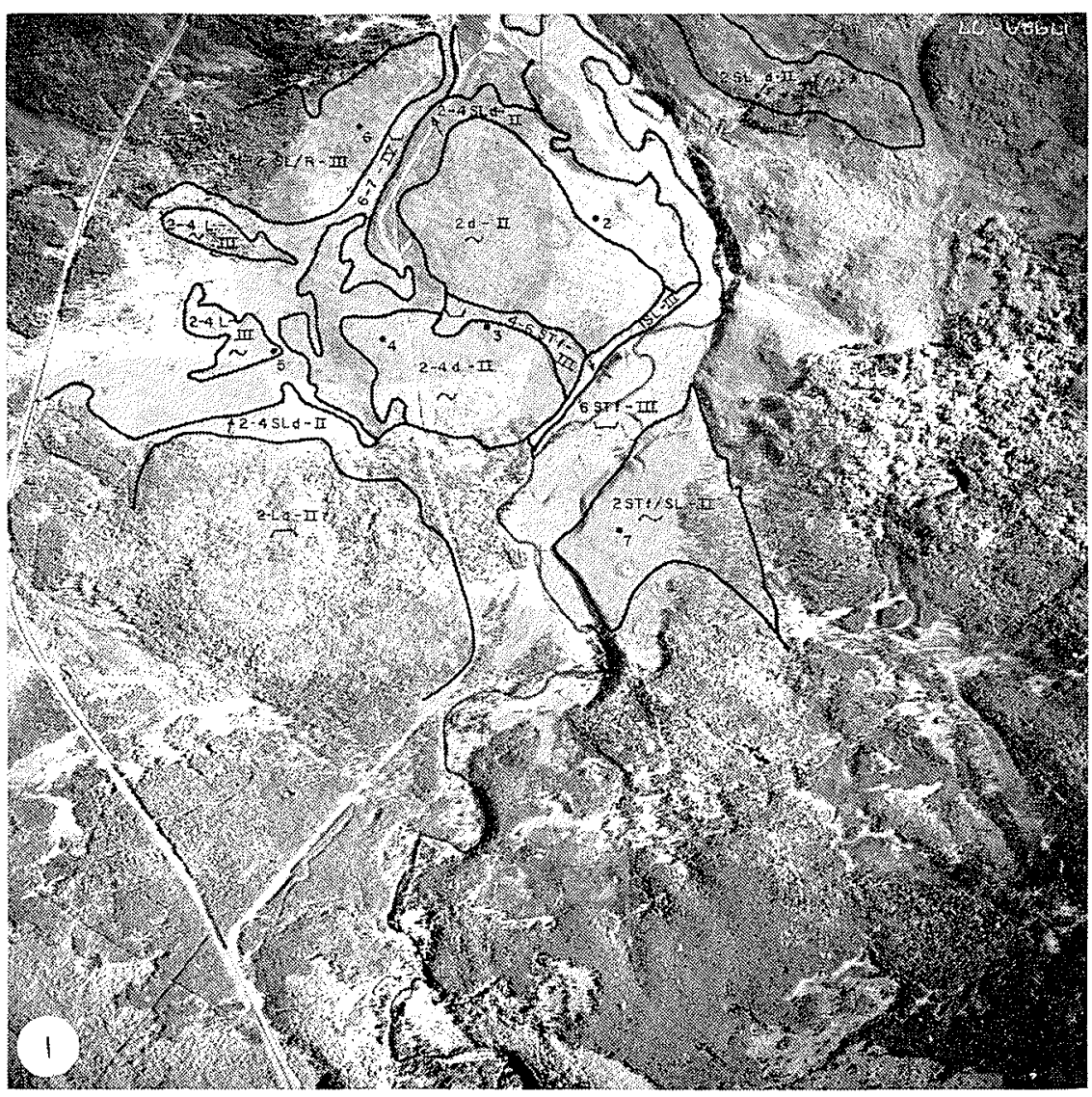

FIGURE 1. Locarions of plors. Site symbols are: $1=\mathrm{dry}$ soil; $2=$ moist soil; 4 =soil wet in spring; ST=silt; $\mathrm{SL}=$ sandy loam; $\mathrm{f}=$ =lluvium; $\mathrm{d}=$ dumped till; $\mathrm{II}=$ productivity good; III=productivity fair.

Figures 2, 3, $6 \& 7$ are on p. 356; $4 \& 5$ are on p. 357; 8-11 are on p. 358.

FIGURE 2. Resin exudation at the root collar is an external symptom of Armillaria mellea. FIGURE 3. White mycclial fele of $A$. mellea under the bark of an infected eree.

FIGURE 6. Western gall rust, Periderminm barkuessiz.

FIGURE 7. Stem canker caused by Cronartium comandrar, accial stage.

FIGURE 8. Elongated canker caused by Periderminm stalactiforme, with aecia and rodent damage.

FIGURE 9. Results of browsing damage: a. leader clipped off; b. a lateral assuming dominance after loss of Iender; c. broon caused by repented browsing.

FIGURE 10. Rodent damage: a. squirrel acrivity confined to rust infected area of tree; b. rabbit girdled tree with dend top; c. partly girdled tree with living top.

FIGURE 11. Pitch module caused by Petrova sp. 
FORESTRY CHRONICLE

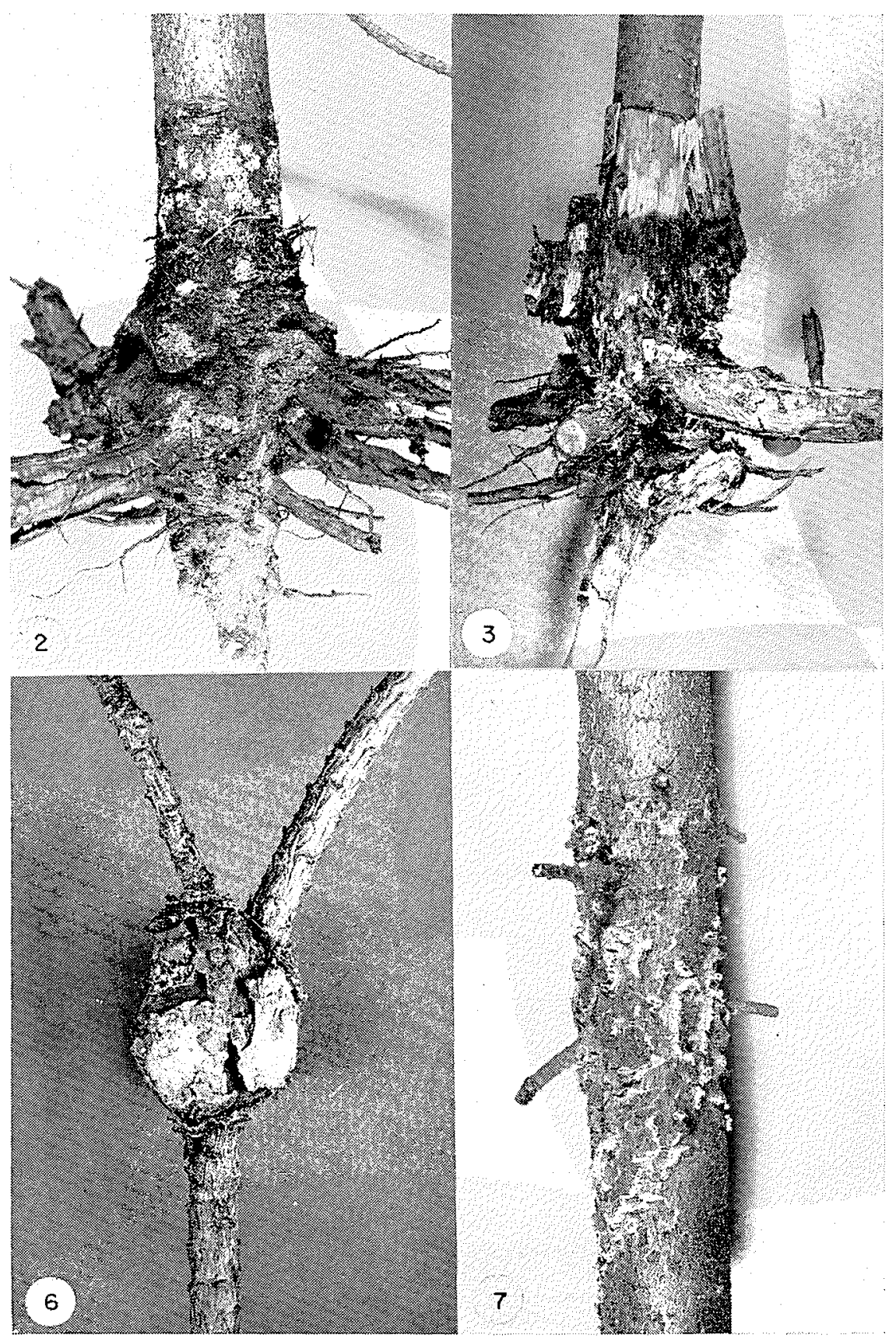




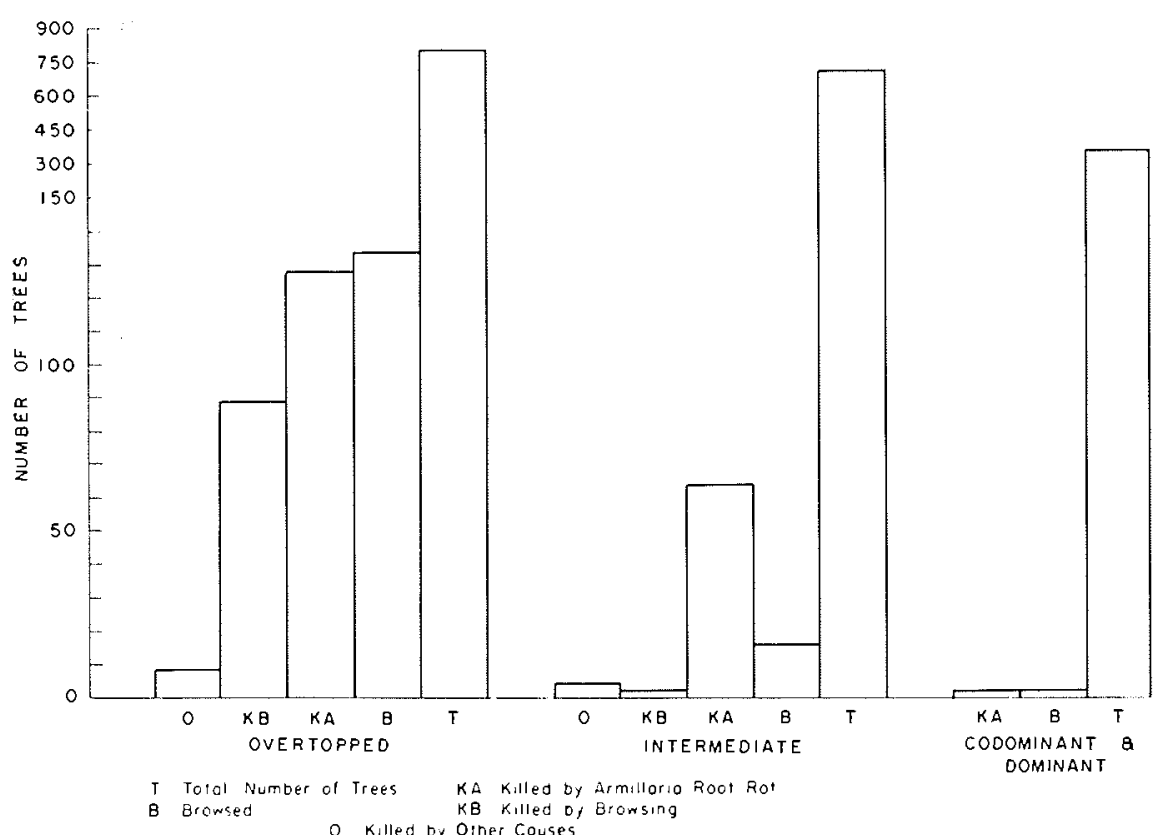

FIGURE 4. Root rot and browsing damage in the various crown classes of lodgepole pine regeneration at Robb, Alberta.

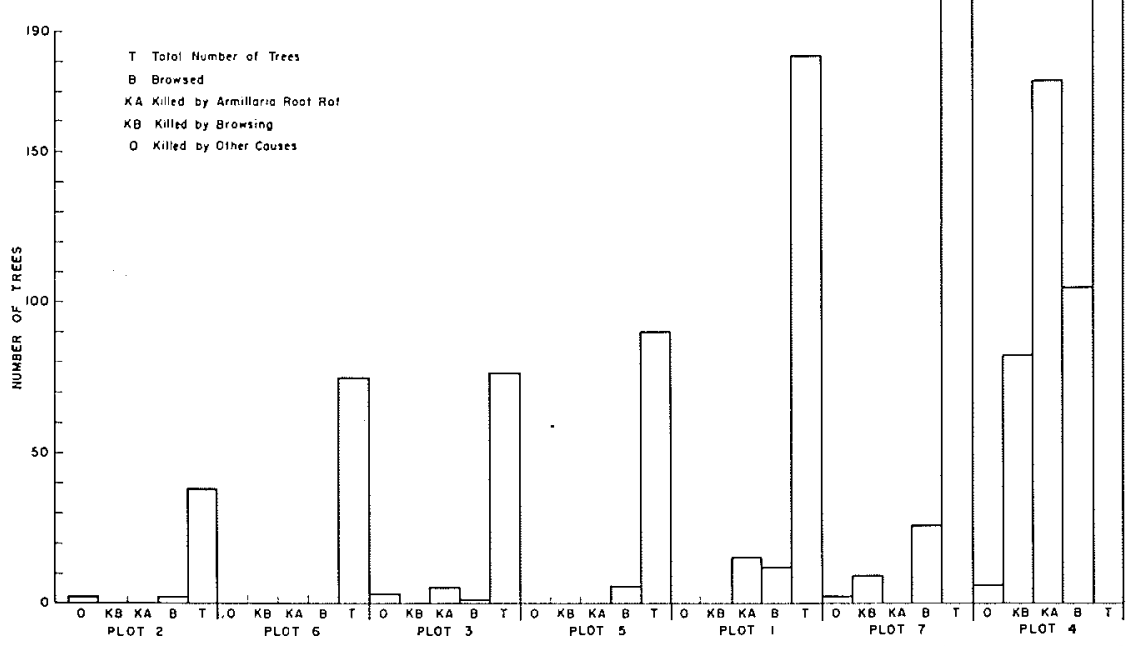

FIGURE 5. Root rot and browsing damage in lodgepole pine regeneration of varying stand densities at Robb, Alberta. Plots are arranged in incrensing order of density from Plot 2 to Plot 4. 


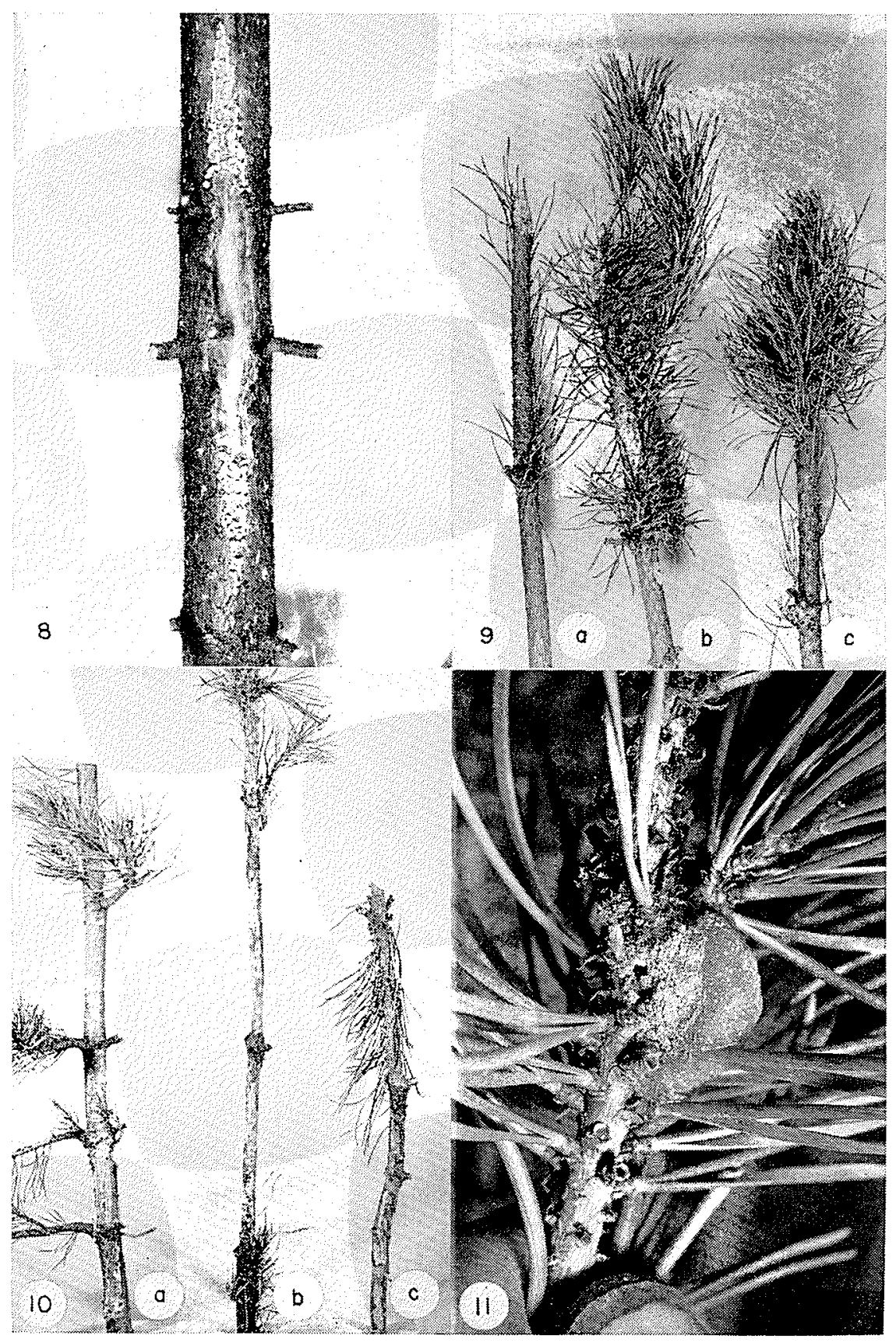


to damage from $A$. mellea (Day, 1927), but structural morphological difference in trees probably have little effect on resistance to the fungus (Thomas, 1934).

At Robb the damage to pine from $A$. mellea (Figs 2, 3) was most evident near the decaying stumps of aspen. In general the tallest trees were the least affected (Fig. 4). Conversely, the plot with the shortest average tree height was the most seriously affected. The higher mortality rate from A. mellea in the smaller trees coincided with overtopping and heavy browsing. Ingrowth and intermediate trees were less damaged than overtopped trees, and mortality of dominants and co-dominants was very low. Stand density, therefore, seems to have been an important factor predisposing trees to serious attack by $A$. mellea (Fig 5).

2. Stem rusts

Stem rusts acting independently of non-infectious agents were much less damaging to pine at Robb than was root rot. Three rusts were present, Peridermium harknessii J. P. Moore (Fig. 6), Cronartium comandrae Peck (Fig. 7), and Peridermium stalactiforme Arth, and Kern (Fig. 8). The first of these occurred most commonly as branch infections and the latter two most commonly as stem infections.

About 75 per cent of the trees infected by $P$. harknessii were dominants and co-dominants, which is characteristic of this fungus. It usually attacks vigorously growing trees and intensifies in an area mainly as branch infections. Mortality resulting from this fungus was low but its incidence had increased from 1959 to 1962, particularly in the more open plots (Table 2). While it is early in the study to predict future losses from this fungus, studies elsewhere have shown that widespread killing is uncommon (Peterson 1960). Economic loss is mainly through degrade and cull caused by trunk cankers (Peterson, 1961) but growth loss is bound to result in trees with a high incidence of branch gall (Table 2, plot 3).

In contrast with $P$. harknessii which does not kill trees readily, $C$. comandrea acts quickly and kills trees by girdling the stem. Stem cankers seldom exceed 3.5 feet in length before girdling occurs (Mielke, 1957). The incidence of this rust at Robb was slightly less than $P$. harknessii but it had similarly intensified in the period 1959-1962. Top killing was common and, unlike $P$. harknessii, about 60 per cent of the infected trees were either intermediates or suppressed. Dying tops were usually infected with the bark beetle Pityogenes knechteli Sw.

Peridermium stalactiforme seems to have been the least damaging rust at Robb, although part of its destructiveness may have been masked by the large number of trees killed by root rot and rodents but which were also infected by the rust. On the whole the incidence of $P$. stalactiforme was low in all crown classes. Unlike $C$. comandrea, this rust proliferates in the bark most rapidly in a longitudinal direction (about 7 inches per year), and cankers up to 30 feet in length can occur without girdling taking place.

3. Pitch nodules

Pitch nodule making insects, Petrova spp., were common at Robb and had increased in numbers from 1959 to 1962 . The damage they have caused 
to date has been negligible, but if the infestation is sustained permanent damage may result. Most of the damage is done in the second year of the two-year life cycle (Turnock, 1953). Damage in the first year is from small larvae that feed in the cortex of shoots while protected by a nodule composed of pitch, silk and frass (Fig. 11). Second-year larvae migrate to the axils of branches and stems where they feed on the bark and wood. Occasionally the leaders and branches of young trees are girdled in this manner, but up to 1962 this had not occurred at Robb.

4. Root weevil

The root weevil Hylobius warreni Wood, was found only occasionally at Robb but is present in large numbers in nearby older stands. Up to the present there have been only a few instances of killing on the plots, but it is too early in the study to evaluate the damage potential of this insect.

5. Browsing

Excellent cover and abundant food has permitted a heavy population of big game at Robb. This has created an important and increasing browsing problem in the burned area. The percentage of trees browsed increased from 3.8 to 13.9 in the period 1959-1962 (Table 2). The damage is distributed unevenly through the area with the smallest trees the most seriously affected (Table 2, plot 4). Most of the damage has occurred at the margins of stand openings. Characteristically leaders are clipped off (Fig. 9a) and if no living branches remain the trees usually die. If a branch whorl remains after browsing has taken place the tree usually survives with one of the laterals assuming dominance (Fig. 9b). With repeated browsing the tree will form a compact terminal broom (Fig. 9c). While the damage is heavy at present and may continue for a few years, it should decrease as the stand becomes older.

6. Rodents

Squirrels and rabbits have caused appreciable damage at Robb. Squirrel activity has been mainly associated with infections of $C$. comandrae and $P$. stalactiforme (Fig. 10a). Rabbit damage was confined to apparently healthy trees (Figs. 10b, 10c). The aggregate amount of rodent damage increased from 1959 to 1962 coincident with an increase of infections by $C$. comandrae. Squirrels feed on rust cankers (Mielke, 1956) by removing diseased bark at the periphery. Depending upon the sizes of cankers. trees are more or less girdled. Heavy resin flow usually accompanies squirrel damage. Rabbits were most damaging in very small trees but squirrels damaged trees of all crown classes. Trees that had been partially or completely girdled by rabbits had usually died within a year.

Interaction of Damaging Agents

It is early in the study to find definite interrelationships between the damaging agents. An indirect interaction seems to have existed between $A$. mellea and browsing. Browsing has contributed to overtopping and general low vigour, each of which seems to have predisposed trees to attack from $A$. mellea. Seventy-five per cent of the trees killed by a combination of root rot, stem rusts and non-infectious agents were browsed and infected with root rot. All of these trees were in the overtopped crown class. 


\section{ACKNOWLEDGMENTS}

The authors wish to thank Mr. D. I. Crossley, Chief Forester, North Western Pulp and Power Limited, Hinton for providing site classification data. Dr. R. T. Ogilvie, Assistant Professor of Botany, University of Alberta, Calgary aided in the identification of plants and assessment of their moisture requirements.

\section{REFERENCES}

BOURCHIER, R. J. 1954. Armillaria root rot of natural lodgepole pine regeneration in Alberta. Can. Dept. Agr., For. Biol. Div., Bi-Monthly Prog. Rept. 10(1):4.

BOYCE, J. S. 1961. Forest pathology. McGraw-Hill Book Co., New York. p. 104.

DAY, W. R. 1927. Parasitism of Armillaria mellea in relation to conifers. Quart. Journ. Forestry, 9-21

DAY, W. R. 1929. Environment and disease. A discussion on the parasitism of Armillaria mellea. Forestry, 3:94-103.

GREIG, B. J. W. 1962. Fomes annosiss (Fr.) Cke and other root-rotting fungi in conifers on ex-hardwood sites. Forestry, 35(2): 164-182.

MIELKE, J. L. 1956. The rust fungus (Cronartium stalactiforme) in lodgepole pine. Jour. Forestry, $54(8): 518-521$

MIELKE, J. L. 1957. The Comandra blister rust in lodgepole pine. U.S. Forest Serv., Intermountain Forest and Range Expt. Sta. Res. Note 46, pp. 1-8.

PETERSON, R. S. 1960. Western gall rust on hard pines. U.S. Dept. Agr., Forest Pest Leaflet 50, pp. $1-8$.

PETERSON, R. S. 1961. Western gall rust cankers in lodgepole pine. Jour. Forestry, 59(3): 194-196.

ROWE, J. S. 1959. Forest regions of Canada. Can. Dept. of North. Aff. and Nat. Res., Forestry Br., Bulletin 123, pp. 1-71. Ottawa.

THOMAS, G. P., BOURCHIER, R. J. and A. A. LOMAN. 1959. Forest disease survey, Province of Alberta. Its Ann. Rept. of the For. Insect and Disease Survey. Can. Dept. Agr., Ottawa.

THOMAS, H. E. 1934. Studies on Armillaria mellea (Vahl) Quél., infection, parasitism, and host resistance. Jour. Agr. Research, 48: 187-218.

TURNOCK, W. J. 1953. Some aspects of the life history and ecology of the pitch module maker Petrova albicapitana (Busck) (Lepidoptera-Olethreutidae). Canad. Ent. 85(7): 233-243. 